\title{
The Study of the Application of Communicative Teaching Approach in Higher Vocational Business English Class
}

\author{
Xiaoxue Xiang \\ Xiangyang Vocational and Technical College, Xiangyang, 441000, China
}

Keywords: Communicative Teaching Approach; Higher Vocation; Business English

\begin{abstract}
Along with the constant development of Chinese economy, cross-cultural communication and foreign trade gain prosperity increasingly, so the ability of business English becomes more important. Training the personnel who are proficient in business English has significance on the development of improving Chinese culture, economy and politics. Through the discussion of the concept, meaning and related problems of communicative teaching approach and by combining with the characteristics of higher vocational English class, this text explores the efficient application of communicative teaching approach in higher vocational business English class, the optimization of the educational effect in higher vocational business English class, the enhancement of the educational level of higher vocational business English and the improvement of students' ability to apply business English.
\end{abstract}

\section{Introduction}

According to the Basic Requirements about the Teaching of the Higher Vocational Business English Course, higher vocational business English mainly cultivates the advanced and professional personnel in such areas as technology, management and service. Higher vocational business English needs to strengthen not only the students' English language basis, but also the concern about the cultivation of the students' application about business English especially the key cultivation about the reinforcement of the handling ability of daily English and English business concerning foreign affairs. ${ }^{[1]}$ Although most higher vocational colleges have set up the business English class and made it as one of the compulsory courses, there exist a lot of problems in the higher vocational business English class at present due to various factors such as teachers, students and the colleges. The problems including the unreasonable class setting, the weak Chinese language proficiency of the students, the single mode of teaching and the teachers' poor application level of business English all have influence on the teaching quality of the business English class. ${ }^{[2]}$ Therefore, solving these problems is conducive to the improvement of the teaching quality of higher vocational English class and the students' professional enthusiasm for the study of higher vocational business English.

\section{The Relationship between Communicative Teaching Approach and Higher Vocational Business English}

\section{The theoretical foundation of communicative teaching approach}

Communicative teaching approach which is the notional approach, functional approach and the function-notion approach, was formed in 1970s and was deeply influenced by many subjects such as linguistic philosophy, sociolinguistics and psycholinguistics. At present, communicative teaching approach has become the teaching method and means in higher vocational business English widely accepted by people. Communicative teaching approach attaches great importance to the language communicative ability of the students and it regards language as a social vehicle of communication. Since language learning cannot break from the social situation of foreign language application, it advocates setting the specific teaching scheme and contents by taking the specific communicative function projects(greeting, catering, tourism and shopping ) as the main clue, further confirming the training objectives and strengthening the teaching pertinence according to students' requirements about future work. At the same time, communicative teaching approach emphasizes that in the class, 
the students should be the center and the teachers act the role of organizer, participant and promoter so as to avoid the disadvantage of traditional teaching in which 'the form is valued and the content is ignored', 'the study of language system is valued and the language application ability is belittled'. ${ }^{[4-5]}$ Therefore, communicative teaching approach truly realizes the communicative function of language and has significant application value in higher vocational business English class.

\section{Communicative teaching approach has the following characteristics ${ }^{[6]}$}

(1) Communicative teaching approach takes improving the language application ability and communicative ability of the students as the main goal; (2)Communicative teaching approach lay stress on the key cultivation of language communicative ability in classroom teaching and is not confined to the mere exercise of language ability and grammar. (3)Communicative teaching approach demands a real situation in class teaching which can promote emotional anxiety and language anxiety. (4)Communicative teaching approach considers the students as the teaching subject and in the class teaching activities, the students are the center while the teachers are the encourager, consultant, coordinator and organizer. (5) It doesn't criticize or correct language errors but encourages students to take an active part in the verbal communicative activities, be brave and willing to communicate. (6)It establishes the foreign language teaching system which regards the function projects as the principle and sets up function projects such as daily reception, international logistics, business conference, marketing and business tourism.

\section{The teaching goal of higher business English class}

The educational objectives of higher vocational business English class needs to combine with the requirements of the cultural development of market-oriented economy and regards training the personnel in foreign-related enterprises, public institutions, commercial industry trade, management and service as the main development goal. Higher vocational business English should train proficient and high-quality personnel who possess good English communicative ability and the comprehensive ability to handle international trade. Graduates of higher vocational business English can be qualified for jobs such as international trade, interpretation, translation, foreign reception and conference; at the same time, graduates of higher vocational business English can work on the operating post such as exhibition service of international commerce, shipping operation, shipping service, foreign service, sales department, public relations department, business department, business assistant, business interpretation and import and export practice.

\section{The teaching characteristics of the higher vocational business English class}

The biggest characteristics of higher vocational business English teaching are the combination of English language skills and the business knowledge. The particularity of the profession determines that teachers should emphasize the training of application and handling ability of English language during the period of class teaching activities in order to highlight the important position and significance of communicative teaching approach in classroom teaching of higher vocational business English. ${ }^{[7]}$

\section{The Application of Communicative Teaching Approach in Higher Vocational Business English Class}

According to the theoretical basis of communicative teaching approach, the characteristics of communicative teaching approach and the teaching goal of higher vocational business English class, teachers should abide by the three basic principles of communicative teaching approach in the classroom teaching design of the higher vocational business English: meaning principle, task principle and communication principle. Setting up simulation scenarios and scenes in classroom activities of higher vocational business English can fully mobilize the initiative and enthusiasm of the students and promote language application and study through completing the task with practical significance during the period of communicative activity. 


\section{The selection of teaching materials for higher vocational business English class}

Teachers should adopt the teaching materials which are close to real life and practical in society for the higher vocational business English class, guide the students get into the role quickly, stimulate students' enthusiasm about activity involvement and encourage them to take an active part in teaching activities through integrating the reaching materials of higher vocational business English which interests the students and combine the business English knowledge and communicative activities efficiently so as to improve their business English translation, oral English and application ability. At the same time, the combination of classroom teaching about higher vocational business English and communicative teaching approach can be applied effectively in aspects such as the introduction of tourism attractions, brief introduction of the company, business documents, shipping items and production introduction. The application of the excessively uncommon, boring and professional teaching materials like the medical reports and thesis of scientific practice should be avoided.

\section{Teachers' selection about teaching scheme}

During the long-term classroom teaching activities of higher vocational business English, in most English classes, teachers teach too much while students speak less and there's little time for the communicative interaction in English between teachers and students and among the students, which causes the poor application ability of oral English, interpretation and verbal communication of the students in the classroom teaching of higher vocational English or even results in that it is hard for some graduates of higher vocational business English to go on daily life, the interaction and communication in English during the working period. It decreases the teaching quality remarkably. ${ }^{[8]}$ During the period of classroom teaching activities of higher vocational business English, the teachers even communicate in Chinese, which is difficult to reach efficient and high-quality teaching goal. In the classroom teaching activities of higher vocational business English, communicative teaching approach requires the teachers to organize classroom teaching activities in English as much as possible and provide the real communication form and environment. During the period of group discussion and activities for the students of higher vocational business English, teachers had better perfect the assignment work before the class to be fully prepared for the smooth and efficient proceedings of English communicative activities. In addition, they should guarantee the quality, high-efficient and smooth conduct of communicative activities through organizing and collecting the vocabulary and common sentences related to the communicative projects or topic and excluding the lexical problems occurred in listening, speaking, reading and writing of English, which helps cultivate the students' ability of listening, speaking, reading and writing.

The Design Principle of Classroom Teaching of Higher Vocational Business English Based on Communicative Teaching Approach

The classroom teaching design of higher vocational business English based on communicative teaching approach requires that during the period of students-centered classroom teaching of higher vocational business English, the teachers should let the students be the subject and act as the leading actor in the English communicative activities, encourage them to use English actively, train their interest in participating in the English communicative activities and make them fully experience the pleasure of taking part in English communicative activities, which helps improve the teaching efficiency. First of all, teachers can be the organizer of classroom teaching activities of higher vocational business English based on communicative teaching approach. During the period in which the activities of communicative teaching are organized, they should make it clear for the students about how to participate in the activities, stimulate their participation awareness about English communicative activities, master how to make students effectively grasp the key and difficult points of business English in English communicative activities, train their common applied skill of business English such as oral English, translation and application.

Secondly, during the period in which the teachers are organizing the classroom teaching activities of higher vocational business English based on communicative teaching approach, teachers should grasp the difficulty of business English strictly and follow the principle from simple to complex and of gradual improvement. They should conduct group training according to the students' ability of 
basic knowledge. As to students with poor foundation, they should arrange the English communicative projects or topics which are easy so as to avoid the situation that student lose the interest in English due to the difficult task; at the same time, they should improve the basic English ability of the students with poor foundation through methods such as extra-curricular tutoring and increase the difficulty of projects or topics of English communicative activity by adopting the principle of gradual improvement in order to enhance the students' ability of English application. Therefore, the classroom teaching design of the higher vocational business English based on communicative teaching approach lay emphasis on business spoken English, the training of translation ability and the communicative application ability of English.

The classroom teaching design of the higher vocational business English, which is based on communicative teaching approach, considers the flexible teaching activities as principles. During the period of classroom teaching of higher vocational business English, teachers do not need to translate word for word, but need to merge the whole communicative activities into the simulation scenario. They should make the students fully understand it through communication and master the application ability of knowledge and language skills in the repetitive process. Under the guidance of communicative approach, teachers can correlate the classroom teaching design of higher vocational business English with business knowledge and design the attractive and practical English communicative activities. (1) Scenario simulation: Teachers integrate the business English courses into the real training room through setting up simulation scenes or simulation scenarios. In this way, they change the boring atmosphere of classroom teaching into the vivid scenario which can fully develop their creativity. For example, in the business English classroom in which the topic is about the 'daily work', teachers can take advantage of the equipments such as reception desk of the training room, the computer, the office table, multi-function printer, phone, record and file to make them truly experience the daily office work including answering phone in daily office work, application of office supplies, reception, receiving customers and conference preparations. Through this method, it's easy for them to be emerged into the scenario, avoid the bad habit, fully train their language communicative ability and strengthen their application ability about body language communication. (2)Group discussion. Make 4 to 6 students as one group and then conduct the group discussion. The students can focus on the agreed topic and every group designs the different topics. According to the required time, the students conduct profound discussion about the related topics of higher vocational business English, then the group representatives make a statement and are evaluated. For example, teachers can design 'what should be prepared for business travel' as the topic and then make the students proceed profound discussion about the aspects such as preparing the goods, booking the tickets, getting aboard and checking in hotel for the students to master the common conversation expression in business travel. The group discussion helps develop their thinking capacity and language expression ability and enhance the teamwork spirit.(3) The making of real documents. Students can be arranged to make the foreign trade documents related to practice such as commercial invoice, insurance policy, postal order and sales order, etc according to the business English they've learned. It not only increases their learning ability about foreign trade, but also their understanding about vocabulary about business English. (4)Role play. In the classroom teaching activities based on communicative teaching approach, teachers must select the targeted topics, design different roles and context so that the students can participate in it. Teachers set the contents such as 'dining in a restaurant', 'checking in hotel' and 'meeting at the airport', complete the background introduction and provide the common vocabulary and the reference sentences. Then students play the roles of receptionists and customers. Taking advantage of certain time for full preparation, students play the role in specific time. Teachers can also offer the knowledge related to business etiquette during the period of role play to mobilize the students' enthusiasm about the participation into the business English communication and promote their application and sentence expression about business English vocabulary. 


\section{Conclusion}

This text conducts a systematic analysis about the theoretical foundation of communicative teaching approach, the characteristics of communicative teaching method and the training goal of the classroom higher vocational business English as well as a systematic introduction about the application of communicative teaching method in improving the classroom teaching quality of higher vocational business English and the application about how the communicative teaching approach guides the selection of the teaching materials in higher vocational business English class and teachers' selection of teaching scheme in classroom activities of higher vocational business English. The classroom teaching of higher vocational business English based on communicative teaching approach means to integrate the communicative teaching approach into the classroom teaching activities of higher vocational business English, which helps mobilize their enthusiasm for study, guide them to simulate the real communicative activities of business English and improve the English communication ability of the higher vocational business English graduates. Therefore, communicative teaching approach is one of the main methods in classroom teaching activities of higher vocational business English, but other teaching methods cannot be denied. Fully developing the effect of interaction between communicative teaching method and other teaching methods contribute to the enhancement of teaching quality. It needs further research and exploration about the value of organic combination between communicative teaching approach and other teaching approaches in classroom teaching of higher vocational business English.

\section{References}

[1] Chen Yihan. A Brief Discussion about the Application of Communicative Teaching Approach in Intensive Reading of Business English. Journal of Xiamen Educational College, 2011,13(4):42-44.

[2] Liu Sichen. A Brief Discussion about the Application of Communicative Teaching Approach in Business English. Huazhang, 2013,(28):207-207.

[3] Guoyin. The Application of Communicative Teaching Approach in Business English. Liaoning Technical Institute of Economics Liaoning Institute of Economic Management, 2011,(3):101-102.

[4] Yue Fengmin. The Reading Class Design of Business English under the Guidance of Communicative Teaching Approach. Jiangsu Scientific and Technological Information, 2013,(15):36-38.

[5] Yin Xueyan. Communicative Teaching Approach and the Teaching Requirement of Business English in Independent Colleges. Journal of Nanchang College, 2011,(2):87-88.

[6] Qianjin. A Brief Analysis about the Application of Communicative Approach in Business English Teaching. Journal of Changchun Educational Institute, 2013,29(13):135,137.

[7] Zhang Linlin. The Exploration and Practice of Communicative Teaching Approach in Business English. Education Science \& Culture Magazine, 2009,(35):153-153.

[8] Yang Yujiao. The Exploration and Study about the Communicative Teaching Approach in Business English Cources-Combining with the Teaching Practice of the Business English Courses. Reading, Writing and Arithmetic(Education and Teaching Research) , 2012,(24):266. 